\title{
Customer relationship management: Are software applications aligned with business objectives?
}

\author{
M.L. Hart* \\ Department of Information Systems, University of Cape Town, \\ Private Bag, Rondebosch 7701, Republic of South Africa \\ mhart@commerce.uct.ac.za
}

Received January 2006

\begin{abstract}
Customer relationship management (CRM) can be thought of as IT-enabled relationship marketing. It has numerous definitions and perspectives, and success of implementation has been limited to date. This paper examines recent literature on the subject, drawing attention to the importance of a balance between strategy formulation, IT and organisational alignment when adopting and implementing CRM. It then discusses results of an exploratory study carried out amongst 34 South African organisations on their business objectives for CRM, the CRM applications that they have invested in or are considering, and the extent of integration of their customer data. The most important objectives and most widely used CRM applications are determined, and associations between applications and objectives are analysed. It is not apparent that CRM applications are selected in line with business objectives, and expected associations with objectives often do not exist for the objectives rated most important. Only certain aspects of customer data integration are significantly linked to objectives or CRM applications. The study suggests the need for fuller determination of strategy and objectives when involved with CRM investigation and adoption, and co-ordination at all levels of implementation between Marketing and IT.
\end{abstract}

*To whom all correspondence should be addressed.

\section{Introduction}

Customer relationship management (CRM) has emerged in recent years as the convergence of a number of factors. Berry (1983) coined the term 'relationship marketing', which encouraged a new movement towards customer relationships rather than customer transactions (Christopher, Payne \& Ballantyne, 1991). Peppers and Rogers (1993) promoted the concept of one-to-one marketing and of mass customization, and Reichheld (1996) further motivated companies with his research on loyalty and empirical evidence of the profitability of customer retention. Customer lifetime value (CLV) has become a key element of CRM. Largely since the early 1990s major performance/price improvements in the speed of processing and size of computer storage, developments in client-server technology, databases and data warehouses, communications technology, and the rapid spread of computer literacy, Internet connectivity and eCommerce into the consumer arena have facilitated the wide application of these ideas. Recently there has been a surge of interest from software vendors and consultants, with CRM being one of the main three-letter acronyms promoted to follow the earlier installation of ERP systems, Y2K and the internet bubble.

However, CRM has had a very uneven track record and reputation. Over the past five years there have been many varied forecasts of the expected growth in sales of CRM, not all of which have been met (Chen \& Chen, 2004; Cosgrove Ware, 2003; Rigby, Reichheld \& Schefter, 2002; Zablah,
Bellenger \& Johnston, 2004a \& b). While there are undoubtedly many successes, much of the research (Gartner Group, 2003; Kale, 2004; Nairn, 2002; Roberts, Liu \& Hazard, 2005; Yu, 2001) mentions the many failures and unmet expectations. Zablah et al. (2004b) provide a table of different failure measures with rates from $35 \%$ to $75 \%$. This appears to echo to a fair extent the history of BPR and ERP, and it seems as if the corporate world has not learnt adequately from past failures and inappropriate implementations.

One major problem is the lack of a common conceptualization of CRM (Bull, 2003; McKim, 2002; Payne \& Frow, 2004; Sin, Tse \& Yim, 2005; Zablah et al., 2004a). Greenberg (2001: 4) notes '[CRM]...isn't a technology. As you will see, that's true, but not strictly. I also heard that it was a 'customer-facing' system. That it is a strategy and/or a set of business processes. A methodology. It is all of the above or whichever you choose'. A literature review by Zablah et al. (2004a) 'yielded approximately 45 distinct definitions of CRM'.

An aspect that has caused confusion, and been oversold by enthusiastic vendors, is the role of information systems or IT in CRM. By using IT effectively, CRM extends the range and reach of relationship marketing (Goodhue, Wixom \& Watson, 2002). Technology is but one of the drivers of success, and a necessary but not sufficient component in the current corporate environment (Kale, 2004; Roberts et al., 2005). Ryals and Knox (2001) state 'IT is the glue' that holds together the philosophical bases of a relationship 
orientation, customer retention, and superior customer value created through process management. CRM was rated the tenth most important information systems management issue in a recent South African study (Hart, Berkowitz, Ryan, \& Waspe, 2004). A 2003 survey by the United States Society for Information Management (SIM) ranked CRM $8^{\text {th }}$ in the list of application and technology developments, while executives with $30+$ years of industry experience placed it $1^{\text {st }}$ (Luftman \& McLean, 2004). In a follow-up study (Luftman, 2005), CRM was ranked $11^{\text {th }}$ by CIOs and $7^{\text {th }}$ by other IT executives.

As with any implementation that has far-reaching impacts, a well-considered vision and strategy are essential (Rigby et al., 2002). In a European study by Peterson (2003), 'Clear eCRM goals and objectives' was rated 4th in a list of 20 strategic capabilities. As yet no work appears to have been carried out that links the selection and use of CRM application software to the business objectives for CRM in the organisation. This paper reports on an exploratory study that aims to discover whether there is alignment between these two aspects, also examining the level of integration of information from the customer viewpoint. The paper starts by examining literature on the subject, then describes the research objectives and methodology. Results of research into CRM use in a sample of South African organisations are analysed and discussed. Finally conclusions are drawn and recommendations made to academics and management.

\section{Literature review}

From the research point of view, CRM is a young and immature field, with little strong empirical research to date (Mithas, Krishnan \& Fornell, 2005). A review of all CRM literature up to 2001 (Romano \& Fjermestad, 2002) found that a cumulative tradition had hardly emerged, with fewer journal articles than conference proceedings and little theoretical development. Literature to end-2002 was summarised by Ngai (2005), and to end-2004 by Paulissen, Milis and Brengman (2005), who found that adoption, acquisition and use of CRM had received good attention, but suggested more could be published on the implementation of CRM. Empirical validation of the impact, benefits and performance of CRM includes work by Chen and Ching (2004), Jayachandran, Sharma, Kaufman and Raman (2005), Mithas et al., 2005; Reinartz, Krafft and Hoyer (2004), and Verhoef (2003). There has been little, if any, empirical academic research into CRM in South Africa: work related to the area includes Abratt and Russell (1999), Brink and Berndt (2004), and Van Zyl (2005). This literature review will focus on aspects of CRM relevant to the study described in this paper.

The CRM definition analysis of Zablah et al. (2004a) yielded five major perspectives: a process, a strategy, a philosophy, a capability, and a technological tool. Some authors (e.g. Rigby et al., 2002) combine two or more of these. Sin et al. (2005) developed a validated scale for CRM consisting of the four factors: key customer focus, CRM organisation, knowledge management, and technology-based CRM.

\section{CRM process}

The process perspective (Reinartz et al., 2004) is the only perspective to acknowledge the lifecycle aspect of the relationship, and has been examined at two levels - one of managing interactions with the customer, the other at a broader macro level incorporating a wider range of activities (Zablah et al., 2004a). Suggesting that the macro-process view offers the best conceptual basis for describing CRM, Zablah et al. (2004a) propose this definition: 'CRM is an ongoing process that involves the development and leveraging of market intelligence for the purpose of building and maintaining a profit-maximizing portfolio of customer relationships'. Payne and Frow (2004) define five important cross-functional processes: strategy development, value creation, multi-channel integration, information management, and performance assessment.

Kumar and Reinartz (2006: 20-21) refer to three generations of CRM since the mid-1990s: firstly functional, then a customer-facing front end approach, and since the end of 2003, strategic. The third generation has a greater focus on integrating the customer-facing front-end systems with the back-end and ERP systems, partners and suppliers.

\section{Models and frameworks, strategy and objectives}

Various models and frameworks have been proposed to show how CRM can be effectively implemented and managed, and to illustrate the process (e.g. Pan \& Lee, 2003; Park \& Kim, 2003; Reinartz et al., 2004; Roberts et al., 2005; Sigala, 2004 \& 2005; Xu \& Walton, 2005; Winer, 2001; Zablah et al., 2004a). Many of these stress the need for sound vision and strategy, followed by proper assessment and setting of business objectives and processes required, before any consideration of technology. Reinartz et al. (2004) suggests a lack of defining objectives as a reason for ineffective CRM technology deployments. Chen and Chen (2004) illustrate how reasons for eCRM adoption may vary, and Roberts et al. (2005: 319) argue that the ultimate objective is CLV. Hart, Hogg and Banerjee (2004) note that 'refinement of [CRM] conceptualization and process is reflected in the need for developing more specific objectives for CRM.' Their factor analysis of ten CRM objectives produced three factors, customer relations enhancement, cost reduction and business development, explaining 59\% of the variance. A December 2004 survey by Gartner (Thompson, 2005) on the primary focus of CRM-related projects in 209 organisations gave the top desired objectives as (in order) increased customer satisfaction; reduced costs of sales, service and marketing; increased sales revenues; reduced costs of other operations; increased profit per customer; and increased customer retention.

Goodhue et al. (2002) discuss three CRM 'targets': applications, infrastructure and transformation, suggesting that 'successful CRM probably requires hitting all three targets, at least to some degree. Ryals and Knox (2001) stress the importance of a solid business case for CRM investments, with enterprise-wide agreement, while Payne and Frow (2004) point out the need for a multi-channel strategy to lead to specific quantified objectives. Success factors for CRM have been explored by Chen and Chen 
(2004), Croteau and Li (2003), Rigby et al. (2002), Ryals and Knox (2001) and Zablah et al. (2004a \& b).

\section{The role of technology}

A few authors (e.g. Chen \& Chen, 2004; Pan \& Lee, 2003; Peterson, 2003) use the term eCRM as either an expanded version of CRM, its extension to other electronic channels and integration with other systems, or as a focus on the technological aspects of CRM. CRM technology and its promotion by vendors and consultants has in recent years been the driving force in publicizing the concept of CRM. An unbalanced focus on the technology has also been the cause of many failures and implementation problems (Chen \& Popovich, 2003; Rigby et al., 2002; Zablah et al., 2004a). Zablah et al. (2004b) warn of process-technology gaps. Reinartz et al. (2004) found that the level of CRM technology did not significantly moderate the links between economic performance and either relationship initiation or relationship maintenance, but suggest that the situation might improve in future when employees are more accustomed to the technology.

\section{CRM technical architecture and applications}

CRM applications architecture can be broadly divided into analytical vs operational (Goodhue et al., 2002), customerfocussed vs operations-focused (Karimi, Somers \& Gupta, 2001: 129), operational, analytical and collaborative (Karimi et al., 2001; Sigala, 2004). Zablah et al. (2004b) categorize CRM technology by the function it supports (sales, marketing and service and support), and its functionality: either to help co-ordinate tasks, automate routine tasks, provide detailed insight, or standardize common tasks and processes. Discussing Gartner's Hype Cycle for CRM marketing applications, Collins, Herschel and Sarner (2005) point out the relative immaturity of the marketing application market, but state that Marketing currently has a more strategic role in CRM, and that there should be stronger adoption of marketing technologies and applications. There is a wide range of CRM application software, packaged differently by different vendors, and with varying degrees of integration. Pan and Lee (2003) give a high level CRM application classification into information integration, customer analysis, campaign management, real time decision-making and personalised messaging. CRM application software includes (Goodhue et al., 2002; Karimi et al., 2001; Sigala, 2004; Zablah et al., 2004b) campaign management, customer profiling, churn analysis, propensity scoring, customer profitability analysis, personalisation, call centre technology, contact management, channel integration software, general analytical and data warehouse tools, and sales force automation.

\section{Alignment and integration}

Organisational alignment and cross-functional integration emerge as key aspects for CRM success (Reinartz et al., 2004; Roberts et al., 2005), especially between Marketing and IT (Ryals \& Knox, 2001; Wehmeyer, 2005). ICT and business strategies should be aligned (Chen \& Chen, 2004; Sigala, $2004 \&$ 2005). Selection of CRM technology and applications software should be based on agreed business objectives and processes required (Pan \& Lee, 2003; Reinartz \& Chugh, 2002; Roberts et al., 2005; Zablah et al., 2004a\&b). In both SIM studies (Luftman \& McLean, 2004; Luftman, 2005) the top I.S. management concern was IT and business alignment. Luftman (2005) defines this as 'applying IT in an appropriate and timely way, in harmony with business strategies, goals and needs' and points out that 'this definition addresses both how IT is aligned with the business, and how the business should/could be aligned with IT.'

Key requirements are for CRM to be data-driven (Roberts et al., 2005), and to consolidate all customer-related information into a single view (Pan \& Lee, 2003).

Various types of integration are important in both operational and customer-facing systems: functional integration, data integration, system compatibility, multichannel integration (Chen \& Chen, 2004; Karimi et al., 2001; Pan \& Lee, 2003; Payne \& Frow, 2004; Swift, 2002). Mithas et al. (2005) shows that firms with high supply chain integration benefit more from CRM applications in terms of customer knowledge and satisfaction.

\section{Research definition and objectives}

The literature reveals a lack of consensus on the definition of CRM, and a fairly unimpressive history of CRM implementation. A wide range of application software is available, but there are concerns about its installation before corporate objectives and processes have been fully agreed, and about lack of alignment between IT and other parts of the business. It would therefore be useful to see how opinions varied on the business objectives of investing in CRM application software, and how aligned the selected software appeared to be with these objectives. The main research question for this study is therefore:

\section{What are the key business objectives behind investment in prevalent CRM applications in the South African business arena?}

Related research objectives are:

1. Which CRM applications are currently installed and being considered?

2. How well are the CRM applications aligned with business objectives?

3. How well is information integrated from the customer viewpoint?

\section{Research methodology}

\section{Questionnaire design}

During the literature survey it was found that an instrument aimed at investigating similar research objectives had been developed by Henley Management College in the U.K. (McCalla, 2003), following earlier work (Ezingeard, Nolan, \& Money, 2001; McCalla, Ezingeard, \& Money, 2002). Management of Henley agreed to allow the author use of their instrument, and as the questions for the study had clearly defined and quantitative alternative answers, a 
survey approach was decided on, using a slightly modified version of the Henley questionnaire.

The questionnaire commenced with demographic questions, then listed and described 11 different types of CRM application software, and asked whether these had been invested in, or were under consideration. Four questions then asked participants about the level of integration of their customer-related data and systems. Lastly, the questionnaire contained 26 questions on the business objectives behind CRM investment, to which respondents were asked to indicate their levels of agreement. They were also able to enter any other objectives they thought important for investment in CRM IT, and rate them. These questions are later shown in summary tables for each section of the questionnaire.

The Henley Management College instrument had already been validated and piloted, and for local usage the questionnaire was shortened slightly and slight adaptations were made. It was then piloted amongst a group of CRM users and consultants. Feedback was received regarding certain questions where the layout prevented an easy flow of ideas and the wording was unclear. These changes were incorporated in the final copy of the questionnaire.

\section{Data collection}

The aim was to contact organisations with some CRM experience who could respond meaningfully to the questions, rather than carry out a CRM prevalence-type survey. Respondents were therefore contacted by two approaches. A sample of 120 companies was selected from the Johannesburg Securities Exchange (JSE), and these were contacted by email. Following a limited response, these were telephoned to ascertain they had some involvement with CRM and to contact the most appropriate person, who was emailed the research questionnaire and cover letter. As an added incentive, respondents could request a copy of the final report. In addition, about 50 questionnaires were handed to delegates at CRM sessions of the Gartner 2003 IT Symposium in Cape Town, who tended to be interested in CRM from both strategic and IT viewpoints. In total 34 fully completed questionnaires were received, representing an approximately 20\% response rate from both approaches combined. The lower than hoped for response appeared to be due to a few factors: many from the JSE list were holding and investment companies to whom CRM IT proved not to be relevant, the shortened questionnaire was still considered too long, and symposium delegates were too busy. Responses were captured into Microsoft Excel, allowing for recoding of the few 'Other - please specify' replies, and also transferred into Statsoft’s Statistica.

\section{Demographic profile of questionnaire respondents}

Most respondents came from customer-oriented sectors and larger companies where CRM could be expected to be adopted (See Table 1). Although many had an IT background, all were at director or management level, or else project leaders for CRM projects. A few were consultants specialising in the CRM area.

\section{Table 1: Sampling demographics}

\begin{tabular}{|c|c|c|}
\hline Business Sector & Number & $\%$ \\
\hline Banking / Finance / Insurance & 11 & $31 \%$ \\
\hline Services & 8 & $24 \%$ \\
\hline Consumer / Manufacturing & 7 & $21 \%$ \\
\hline IT & 5 & $15 \%$ \\
\hline Other & 3 & $9 \%$ \\
\hline Total & 34 & \\
\hline \multicolumn{3}{|l|}{ Company Size } \\
\hline Large & 19 & $55 \%$ \\
\hline Medium & 7 & $21 \%$ \\
\hline Small & 8 & $24 \%$ \\
\hline Total & 34 & \\
\hline
\end{tabular}

\section{Analysis of response on objectives}

\section{Mean response for CRM objectives}

The questionnaire listed the following statement: We are interested in understanding the business objectives behind investments in CRM applications. If your organisation has previously purchased a CRM application, think back to that time. If not, we would now like you to consider that you are shortly purchasing a CRM application.

Respondents were then asked to tick one of five boxes from 'strongly agree' to 'strongly disagree' for each of 26 business objectives. These 26 questions and the breakdown of responses are listed fully in Appendix 1. Table 2 lists the 15 objectives rated most important, based on a mean using weights from 1 (strongly agree) to 5 (strongly disagree). The top 15 all lie on average between agree and strongly agree, and the remaining 11 objectives had mean scores from 2,15 to 3,15. 'Other, please specify' objectives addedd were all of low frequency, and were therefore excluded from the analysis.

The objective Improve overall company performance had the highest percentage (94\%) of agree to strongly agree responses. Engender greater loyalty from customers through value added services and Improve our abilities in managing new opportunities or sales leads followed with 91\%. Noticeably Reduce our marketing costs was last of the 26 objectives with only $18 \%$ agreement. Of the top 15 objectives, the $1^{\text {st }}, 5^{\text {th }}, 6^{\text {th }}, 7^{\text {th }}$ and $12^{\text {th }}$ relate to general corporate efficiency or capability, while the remainder are directly customer-related, including three relating to service provision. This is not out of line with the results of Hart, Hogg and Banerjee (2004) and of Thompson (2005). 
Table 2 - CRM objectives ranked by mean score $(1=$ strongly agree to 5 = strongly disagree $)$

\begin{tabular}{l|l|c|c}
\hline Rank & CRM Objective & Mean & Std Dev \\
\hline 1 & Improve overall company performance & 1,65 & 0,60 \\
\hline 2 & Engender greater loyalty from customers through value added services & 1,65 & 0,65 \\
\hline 3 & Improve our abilities in managing new opportunities or sales leads & 1,68 & 0,73 \\
\hline 4 & Enhance the 'customers total experience' & 1,71 & 0,72 \\
\hline 5 & Improve position in the marketplace as a leading edge competitor & 1,74 & 0,83 \\
\hline 6 & Improve business intelligence capabilities & 1,76 & 0,78 \\
\hline 7 & Improve quality of strategic and marketing decision-making capabilities & 1,85 & 0,74 \\
\hline 8 & Improve the consistency of service provision & 1,85 & 0,86 \\
\hline 9 & Improve understanding of customer wants and desires & 1,88 & 0,88 \\
\hline 10 & Improve customer profiling capabilities & 1,94 & 0,81 \\
\hline 11 & Improve our customer retention statistics & 1,94 & 0,92 \\
\hline 12 & Streamline and make business processes more effective & 1,94 & 0,92 \\
\hline 13 & Improve the reliability of service provision & 1,94 & 0,98 \\
\hline 14 & Improve our abilities to target specific customer segments & 2,00 & 0,89 \\
\hline 15 & Improve the responsiveness of our service provision & 2,00 & 0,92 \\
\hline
\end{tabular}

\section{Factor analysis of CRM objectives}

It is difficult to draw conclusions from 26 separate objectives, and a number of exploratory factor analyses were therefore carried out in an attempt to group some of the objectives into major themes. The top 15, top 20, and all 26 objectives were used, together with normalized equamax, quartimax and varimax rotations. Table 3 shows a factor analysis based on the 15 objectives receiving the highest mean scores, with a cumulative variance of 74,4\% explained by five factors. This was supported by Kaiser's criterion, as there were five eigenvalues exceeding 1,0, and it appeared to be reasonable on Cattell's scree plot (Everitt \& Dunn, 1991). Factor loadings and percentage variance explained were higher than those of Hart, S. et al. (2004). Factor 5 had the lowest loadings, between 0,64 and 0,69, which are still acceptable in an exploratory study. The only unallocated objective was one that gained the joint-highest mean score, Engender greater loyalty from customers through value added services. This had split loadings, mainly across Factors 2 and 3.

Some comment will now be made about these factors, and an attempt made to label each with a meaningful 'compound' objective factor or construct. It is clear that some objectives relate directly to the customer, while others are a 'means to the end', supporting internal processes that may facilitate customer satisfaction and retention. Factors often incorporated objectives of both types.
Factor 1: Improve customer profiling and understanding to better manage new opportunities and sales leads.

The three questions in this factor are all in the top 10, have loadings exceeding 0.82 , and explain $18.7 \%$ of the variance. An item analysis to test for internal consistency yields a Cronbach alpha of 0.85 . This factor's overall objective was determined based on the profiling and understanding elements present in the first two questions, applied to the management of new opportunities. This could also be seen to be the conversion process of business intelligence, developed in Factor 2, into customer profiling information which could enhance cross-selling opportunities for the existing customer base. This factor remained constant for analyses carried out on the top 20, and on all 26 objectives.

Factor 2: Improve customer retention statistics and position in the marketplace through business intelligence capabilities.

This factor contributed $17.0 \%$ of the variance, with a Cronbach alpha of 0.72 . The underlying concept is that, through improved analytical capabilities, companies can better discern the demand patterns of their customers, assisting in providing improved service and product targeting and delivery. Thus, companies improve retention of their customers as their needs are met in an effective manner. It was realised after the survey that some confusion may have been caused by used of the word statistics in Improve our customer retention statistics, which could be taken to mean either improvement of retention figures, or improved recording of them. Effective application of business intelligence should also lead to improved competitiveness and market leadership generally. With different rotations applied to the top 20 questions, the customer retention statistics item is excluded from this factor. 
Table 3: Factor analysis of top fifteen objectives (principal components with varimax rotation)

\begin{tabular}{|c|c|c|c|c|c|}
\hline CRM Objective & Factor 1 & Factor 2 & Factor 3 & Factor 4 & Factor 5 \\
\hline Improve understanding of customer wants and desires & 0,8219 & 0,0558 & 0,2130 & 0,0844 & $-0,0101$ \\
\hline Improve customer profiling capabilities & 0,8792 & 0,1243 & $-0,0322$ & 0,0844 & 0,0830 \\
\hline $\begin{array}{l}\text { Improve our abilities in managing new opportunities or sales } \\
\text { leads }\end{array}$ & 0,8583 & $-0,0777$ & 0,1556 & 0,0342 & 0,0356 \\
\hline Improve our customer retention statistics & 0,0513 & 0,8187 & 0,0621 & $-0,0961$ & 0,2552 \\
\hline $\begin{array}{l}\text { Improve position in the marketplace as a leading edge } \\
\text { competitor }\end{array}$ & 0,0805 & 0,6757 & 0,1716 & 0,3819 & $-0,0943$ \\
\hline Improve business intelligence capabilities & $-0,0521$ & 0,7487 & 0,0171 & 0,1096 & 0,0719 \\
\hline Improve the reliability of service provision & 0,1262 & $-0,2165$ & 0,8323 & 0,2595 & 0,1730 \\
\hline Improve the consistency of service provision & 0,0697 & 0,5339 & 0,7134 & 0,0088 & $-0,1833$ \\
\hline Improve the responsiveness of our service provision & 0,3736 & 0,2322 & 0,7523 & $-0,0380$ & 0,1849 \\
\hline Streamline and make business processes more effective & $-0,1328$ & 0,0408 & 0,4390 & 0,7269 & 0,1405 \\
\hline Improve overall company performance & 0,2846 & 0,1439 & $-0,0423$ & 0,8177 & 0,1207 \\
\hline Enhance the 'customers total experience' & $-0,1636$ & 0,3895 & 0,4566 & 0,0124 & 0,6455 \\
\hline $\begin{array}{l}\text { Improve the quality of strategic and marketing decision- } \\
\text { making capabilities }\end{array}$ & 0,1297 & 0,2935 & $-0,0303$ & 0,4499 & 0,6919 \\
\hline Improve our abilities to target specific customer segments & 0,5395 & $-0,2118$ & 0,0524 & 0,0843 & 0,6415 \\
\hline $\begin{array}{l}\text { Engender greater loyalty from our customers through value } \\
\text { added services }\end{array}$ & 0,1122 & 0,3778 & 0,4220 & 0,2832 & $-0,2963$ \\
\hline Variance Explained & 2,803 & 2,546 & 2,457 & 1,738 & 1,614 \\
\hline \% Variance Explained & $18,7 \%$ & $17,0 \%$ & $16,4 \%$ & $11,6 \%$ & $10,8 \%$ \\
\hline Cumulative \% & $18,7 \%$ & $35,7 \%$ & $52,0 \%$ & $63,6 \%$ & $74,4 \%$ \\
\hline Cronbach Alpha & 0,85 & 0,72 & 0,78 & 0,54 & 0,62 \\
\hline
\end{tabular}

Factor 3: Improve the reliability, consistency and responsiveness of service provision, using integrated IT systems to enable delivery across multiple channels.

Table 3 shows three questions relating to service provision, explaining $16,4 \%$ of the variance, with a Cronbach alpha of 0,78. With different analyses these three questions consistently grouped together, but were also incremented by others. With the top 20 analysis, Improve the integration of our IT systems and Enable the delivery of service / products across multiple channels were added to this factor, increasing the Cronbach alpha to 0,85 and the explained variance to $19,2 \%$. This brings in the importance of integrated IT systems in enabling not only the use of multiple channels, but executing delivery effectively and efficiently.

Factor 4: Improve overall company performance by making business processes more effective.
Explaining $11,6 \%$ of the variance, it had a low Cronbach score of 0,54 for its two items Improve overall company performance and Streamline and make business processes more effective. Through improving the operational processes related to CRM, costs can be reduced and a company's performance improved. This suggests process engineering, supply chain management, and likely use of an ERP system. With other factor analyses however, these items loaded differently.

Factor 5: Enhance the customers' total experience through improved strategic and marketing decision-making, and ability to target specific customer segments.

Variance explained was $10,8 \%$ with a Cronbach alpha of 0,62 , which increased to 0,70 if the question relating to targeting specific customer segments was removed. This grouping of three items was not very intuitive, and they factored differently when larger sets of questions were used. The only 'stable' factors across different analyses were Factors 1 and 3, and, to a lesser extent, Factor 2. In later 
analyses it will be seen whether there is any association between these factors and the CRM software applications purchased by organisations.

\section{Applications purchased and under consideration}

Figure 1 shows the extent to which companies had already invested in individual CRM application software components, or were considering purchasing them.

Applications such as analytics (77\%), opportunity and lead management (68\%), call centres (56\%) and campaign management (53\%) have been purchased by the majority of the surveyed companies, with roughly a further $10 \%$ of companies considering them. Apart from these four, and interactive selling applications, it is notable that $50 \%$ or more of respondent companies are not (yet?) considering CRM applications relating to field service, personalisation, content management, partner relationship management, incentive compensation and sales configuration. It is not clear what percentage of purchased items are 'shelfware', or have not yet been implemented.

\section{Factor analysis of applications}

To assess whether the 11 applications formed any useful natural groupings in terms of the data available, factor analysis was also carried out on these. Various rotations and minimum eigenvalues were tried, but the overall impression was that benefits of doing this were limited. The most consistent grouping was of content management, personalisation, and sales configuration software, which accounted for some $22 \%$ of the variance and had a Cronbach alpha of 0.73. Analytical CRM and opportunity and lead management software contributed a further $21 \%$, but had a low Cronbach alpha of 0.58 . These factors were therefore not used in additional analysis.

\section{Relating CRM objectives to investment in CRM applications}

Companies should be investing in CRM applications software that will assist them to fulfil their major CRM objectives and processes (Pan \& Lee, 2003; Reinartz \& Chugh, 2002; Roberts et al., 2005; Zablah et al., 2004a\&b). Even though organisations' objectives vary, each should be installing the applications that are most able to satisfy their own CRM needs. Accordingly, further analysis has been done to uncover significant associations between the level of agreement regarding business objectives and the investment in, or consideration to purchase, specific applications. A positive association would show that those agreeing most strongly with an objective tend to be the ones that have invested in or are considering investment in an appropriate CRM product. This is done for each objective / application combination to illustrate the strength and broad pattern of relationships, not as hypothesis testing.

Analysis has to take into account the categorical (or ordinal, if consideration of an application is viewed as a state between purchased and not considering) level of the applications data, and the ordinal level of the Likert scale for objectives. The Mann-Whitney U test for two independent samples, Spearman's rank correlation, and the GoodmanKruskal Gamma statistic were used. These allow for the non-interval nature of the data, do not require assumptions such as normality, and have statistical power almost equal to their parametric counterparts. Levels of significance shown are $\mathrm{p}<0,05\left(^{*}\right), \mathrm{p}<0,01(* *)$ and $\mathrm{p}<0,001(* * *)$. The Gamma statistic is a preferred alternative to the Spearman rank correlation coefficient, which tends to underestimate the level of significance (p-value) when there are many tied observations (Siegel \& Castellan, 1988). (It may sometimes indicate a relatively invalid association if one of the variables is concentrated on one value, which is rarely the case here). The Gamma will be shown in tables together with other statistics to indicate any possible significant associations, but in discussions Gamma values with $\mathrm{p}<0,05$ $\left(G^{*}\right)$ will be ignored, in order to focus on the stronger linkages.

\section{Associations between objectives and applications}

Table 4 shows the objectives and applications for which there were significant Mann-Whitney (M) and/or Gamma (G) relationships. Objectives are sequenced by mean score, and applications by the percentage who already have them or are considering purchase. Additional checks carried out on the direction of each association using Spearman's rank correlation showed that all significant associations were positive. Partner relationship management was omitted from Table 4, as it had no significant associations with CRM objectives. Three low ranked objectives without significant associations were also excluded. Contrary to expectations, there are more significant associations for CRM objectives that received lower ratings than for those ranked highly.

Certain applications and objectives stand out more than others. Campaign management is related to a range of CRM objectives with rankings from $4^{\text {th }}$ to last. Personalisation is also associated significantly with many objectives, from rank $9^{\text {th }}, 13^{\text {th }}$ and below. Sales configuration is related to a range of objectives from the highest to the lowest ranks. Field service, Partner relationship management and Incentive compensation appear to satisfy none of the objectives. Analytical applications are the most prevalent of all applications, but surprisingly they are significantly linked to only Improve our abilities to target specific customer segments. The other applications are related to only a few objectives of rank 10 and below.

The objective that seems to be best supported by applications is Improve our abilities to target specific customer segments, which is significantly related to the five most frequently purchased applications as well as to Sales configuration. The next two most supported are Improve the responsiveness of our service provision and Reduce our marketing costs. These objectives however rank only $14^{\text {th }}$, $15^{\text {th }}$ and last. The remaining objectives are associated with 0,1 or 2 applications. 


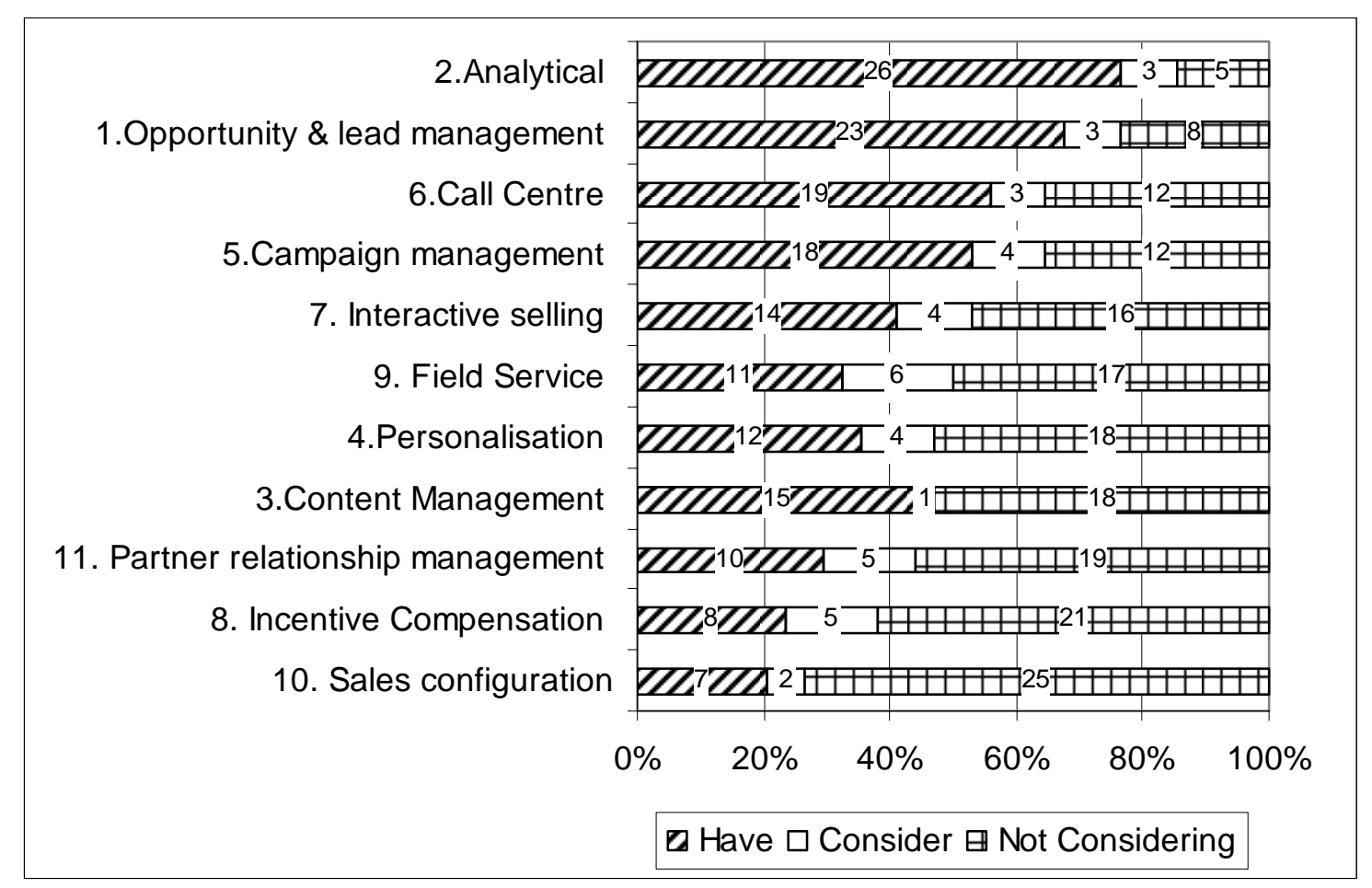

Figure 1: Investment in CRM IT applications

What do these statistics imply? There seems to be sound logic in some of the associations, such as using campaign management to reduce marketing costs. Others are harder to explain. There may be two reasons why there are not more significant associations with analytic applications. Because there are only five respondents who do not have them (and are not considering them), the data is very skewed, and differences in mean objective scores have to be very marked to be statistically significant (such as the objective of targeting customer segments, where those not considering the software have a mean score of 3.2 versus 1.79 for the remaining 29 respondents - note again that 1 implies strong agreement). The second possibility is that they were described as 'technologies that support strategic decision-making processes, ad hoc query, reporting and analysis' (general tools that have existed long before CRM was defined), and not specifically as CRM analytics. It is however strange that the five respondents not considering analytic applications had a mean score of 1.40 for Improve business intelligence capabilities, whereas the other 29 averaged 1.83 .

Some of the broader objectives such as Improve the integration of our IT systems will be served by other software such as ERP systems, and associations with CRM applications are not expected. Certain objectives are related closely in name to CRM applications (lead management, interactive selling, and campaign management), and one might expect to find strong statistical associations, yet there are only two weak Gamma $\left(\mathrm{G}^{*}\right)$ associations. In each case there is slightly stronger agreement with the objectives amongst those who have, or are considering getting the software - it is just not significant enough. There are some clear anomalies, which may point to lack of alignment, or uncertainty about the capabilities of certain applications. For example, the objective of improving customer profiling capabilities is most closely related to opportunity and lead management, rather than to analytical or personalisation applications. It is hard to understand why personalisation is related to certain objectives, but not at all to others, such as greater loyalty through value-added services, enhancing customer's total experience, or improving customer retention statistics. Only a third of respondents have personalisation software, and 53\% are not even considering its purchase. Murthi and Sarkar (2003) conceptualise the personalisation process as three stages: learning about consumer preferences, matching offerings to customers, and evaluation of the learning and matching process. As such it covers a very broad canvas. 
Table 4: Associations between objectives and applications

\begin{tabular}{|c|c|c|c|c|c|c|c|c|c|c|c|c|}
\hline & 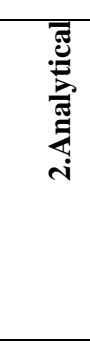 & 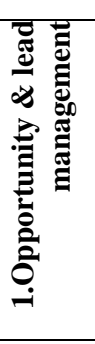 & 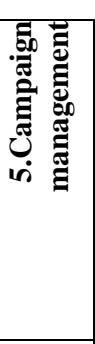 & 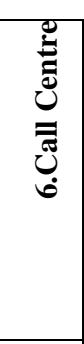 & 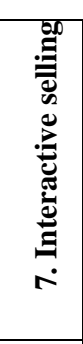 & 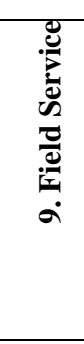 & 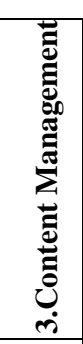 & 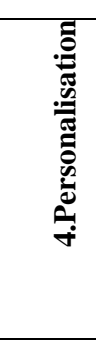 & 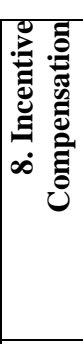 & 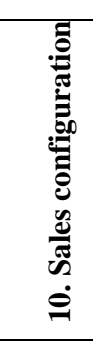 & 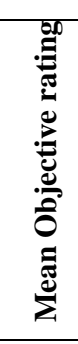 & 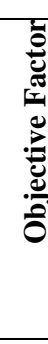 \\
\hline Have Application \% & $76 \%$ & $68 \%$ & $53 \%$ & $56 \%$ & $41 \%$ & $32 \%$ & $44 \%$ & $35 \%$ & $24 \%$ & $21 \%$ & & \\
\hline Have or Considering\% & $85 \%$ & $76 \%$ & $65 \%$ & $65 \%$ & $53 \%$ & $50 \%$ & $47 \%$ & $47 \%$ & $38 \%$ & $26 \%$ & & \\
\hline \multicolumn{13}{|l|}{ CRM Objective } \\
\hline $\begin{array}{l}\text { overall company } \\
\text { performance }\end{array}$ & & & & & & & & & & $\mathrm{G}^{* *}$ & 1,65 & 4 \\
\hline customer loyalty & & & & $\mathrm{G}^{*}$ & $\mathrm{G}^{*}$ & & & & & & 1,65 & \\
\hline $\begin{array}{l}\text { managing new opportunities } \\
\text { / leads }\end{array}$ & $\mathrm{G}^{*}$ & $\mathrm{G}^{*}$ & & & & & & $\mathrm{G}^{*}$ & & & 1,68 & 1 \\
\hline customers total experience & & & $\begin{array}{l}\mathrm{M}^{*} \\
\mathrm{G}^{* *}\end{array}$ & & & & & & & & 1,71 & 5 \\
\hline leading edge competitor & & $\mathrm{G}^{*}$ & & $\mathrm{G}^{*}$ & & & $\mathrm{G}^{*}$ & $\mathrm{G}^{*}$ & & & 1,74 & 2 \\
\hline $\begin{array}{l}\text { business intelligence } \\
\text { capabilities }\end{array}$ & & & $\begin{array}{l}\mathrm{M}^{*} \\
\mathrm{G}^{* * *}\end{array}$ & $\mathrm{G}^{*}$ & $\mathrm{G}^{*}$ & & $\mathrm{G}^{*}$ & & & & 1,76 & 2 \\
\hline $\begin{array}{l}\text { strategic and marketing } \\
\text { decision-making }\end{array}$ & & & & & & $\mathrm{G}^{*}$ & & & & $\mathrm{G}^{*}$ & 1,85 & 5 \\
\hline $\begin{array}{l}\text { consistency of service } \\
\text { provision }\end{array}$ & & & & & & & & $\mathrm{G}^{*}$ & & & 1,85 & 3 \\
\hline $\begin{array}{l}\text { understanding of customer } \\
\text { wants }\end{array}$ & & $\mathrm{G}^{*}$ & & & & & & $\mathrm{G}^{* *}$ & & $\begin{array}{l}\mathrm{M}^{*} \\
\mathrm{G}^{* * *}\end{array}$ & 1,88 & 1 \\
\hline $\begin{array}{l}\text { customer profiling } \\
\text { capabilities }\end{array}$ & $\mathrm{G}^{*}$ & $\begin{array}{l}\mathrm{M}^{* *} \\
\mathrm{G}^{* * *} \\
\end{array}$ & & & & & & & $\mathrm{G}^{*}$ & $\mathrm{G}^{*}$ & 1,94 & 1 \\
\hline customer retention statistics & & & $\begin{array}{l}\mathrm{M}^{*} \\
\mathrm{G}^{* *}\end{array}$ & $\mathrm{G}^{*}$ & & & & & & & 1,94 & 2 \\
\hline business processes & & & $\mathrm{G}^{*}$ & $\mathrm{G}^{* *}$ & & & & & & & 1,94 & 4 \\
\hline $\begin{array}{l}\text { reliability of service } \\
\text { provision }\end{array}$ & & & & $\mathrm{G}^{*}$ & & & & $\begin{array}{l}\mathrm{M}^{*} \\
\mathrm{G}^{* *}\end{array}$ & & & 1,94 & 3 \\
\hline $\begin{array}{l}\text { target specific customer } \\
\text { segments }\end{array}$ & $\begin{array}{l}\mathrm{M}^{* *} \\
\mathrm{G}^{* * *}\end{array}$ & $\begin{array}{l}\mathrm{M}^{*} \\
\mathrm{G}^{* *}\end{array}$ & $\begin{array}{l}\mathrm{M}^{*} \\
\mathrm{G}^{* * *}\end{array}$ & $\begin{array}{l}\mathrm{M}^{*} \\
\mathrm{G}^{* *}\end{array}$ & $\begin{array}{l}\mathrm{M}^{*} \\
\mathrm{G}^{* *}\end{array}$ & & & $\mathrm{G}^{*}$ & $\mathrm{G}^{*}$ & $\begin{array}{l}\mathrm{M}^{*} \\
\mathrm{G}^{* * *}\end{array}$ & 2,00 & 5 \\
\hline $\begin{array}{l}\text { responsiveness of service } \\
\text { provision }\end{array}$ & & $\mathrm{G}^{*}$ & $\begin{array}{l}\mathrm{M}^{*} \\
\mathrm{G}^{* *}\end{array}$ & $\mathrm{G}^{*}$ & $\mathrm{G}^{* *}$ & & $\begin{array}{l}\mathrm{M}^{*} \\
\mathrm{G}^{* *} \\
\end{array}$ & $\begin{array}{l}\mathrm{M}^{* * *} \\
\mathrm{G}^{* * *}\end{array}$ & & $\mathrm{G}^{*}$ & 2,00 & 3 \\
\hline $\begin{array}{l}\text { sell products and services } \\
\text { interactively }\end{array}$ & $\mathrm{G}^{*}$ & $\mathrm{G}^{*}$ & $\mathrm{G}^{*}$ & & & & $\begin{array}{l}\mathrm{M}^{*} \\
\mathrm{G}^{* *}\end{array}$ & $\mathrm{G}^{* *}$ & & & 2,15 & \\
\hline integration of our IT systems & & & & & $\mathrm{G}^{*}$ & & & $\mathrm{G}^{*}$ & & & 2,21 & 3a \\
\hline $\begin{array}{l}\text { direct marketing / campaign } \\
\text { management }\end{array}$ & & & $\mathrm{G}^{*}$ & & & & & & & $\mathrm{G}^{* *}$ & 2,32 & \\
\hline $\begin{array}{l}\text { delivery across multiple } \\
\text { channels }\end{array}$ & & & $\begin{array}{l}\mathrm{M}^{*} \\
\mathrm{G}^{* *}\end{array}$ & $\mathrm{G}^{*}$ & & $\mathrm{G}^{*}$ & & $\begin{array}{l}\mathrm{M}^{*} \\
\mathrm{G}^{* *}\end{array}$ & & & 2,35 & 3a \\
\hline forecasting capabilities & & & & & & & & $\begin{array}{l}\mathrm{M}^{*} \\
\mathrm{G}^{* *}\end{array}$ & & $\mathrm{G}^{*}$ & 2,38 & \\
\hline Reduce operating costs & & & & & & & & $\begin{array}{l}\mathrm{M}^{*} \\
\mathrm{G}^{* *}\end{array}$ & & & 2,50 & \\
\hline $\begin{array}{l}\text { match quotes / packages to } \\
\text { customer }\end{array}$ & & & & & & $\mathrm{G}^{*}$ & & $\begin{array}{l}\mathrm{M}^{*} \\
\mathrm{G}^{* *}\end{array}$ & & $\mathrm{G}^{* *}$ & 2,56 & \\
\hline Reduce marketing costs & & $\mathrm{G}^{*}$ & $\begin{array}{l}\mathrm{M}^{* *} \\
\mathrm{G}^{* * *}\end{array}$ & $\begin{array}{l}\mathrm{M}^{*} \\
\mathrm{G}^{* *}\end{array}$ & $\mathrm{G}^{*}$ & & $\mathrm{G}^{*}$ & $\begin{array}{l}\mathrm{M}^{*} \\
\mathrm{G}^{* * *}\end{array}$ & $\mathrm{G}^{*}$ & $\begin{array}{l}\mathrm{M}^{*} \\
\mathrm{G}^{* *}\end{array}$ & 3,15 & \\
\hline
\end{tabular}

G denotes Gamma Statistic, M is Mann-Whitney; $*=p<0,05,{ }^{* *}=p<0,01, * * *=p<0,001$ 
Table 5: Associations between objective factors and applications

\begin{tabular}{|c|c|c|c|c|c|c|c|c|c|c|c|}
\hline & 矛 & 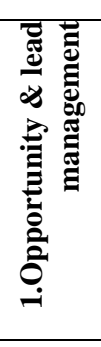 & 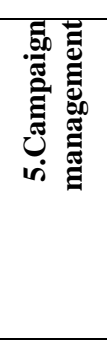 & 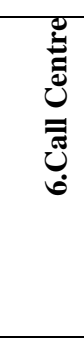 & 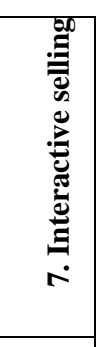 & 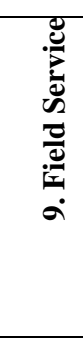 & 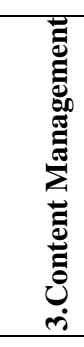 & 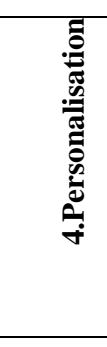 & 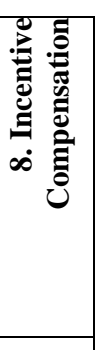 & 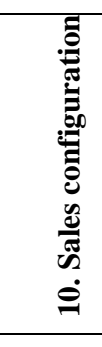 & 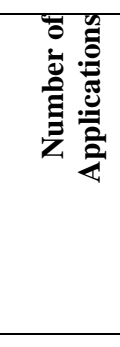 \\
\hline Have Application \% & $76 \%$ & $68 \%$ & $53 \%$ & $56 \%$ & $41 \%$ & $32 \%$ & $44 \%$ & $35 \%$ & $24 \%$ & $21 \%$ & \\
\hline Have or Considering\% & $85 \%$ & $76 \%$ & $65 \%$ & $65 \%$ & $53 \%$ & $50 \%$ & $47 \%$ & $47 \%$ & $38 \%$ & $26 \%$ & \\
\hline \multicolumn{12}{|l|}{ Objective Factor } \\
\hline $\begin{array}{l}\text { 1. Improve customer profiling and } \\
\text { understanding to better manage new } \\
\text { opportunities and sales leads }\end{array}$ & & $\begin{array}{l}\mathrm{M}^{*} \\
\mathrm{G}^{* * *} \\
\end{array}$ & & & & & & $\mathrm{G}^{*}$ & & $\begin{array}{l}\mathrm{M}^{*} \\
\mathrm{G}^{* *}\end{array}$ & $\mathrm{G}^{*} \mathrm{~S}^{*}$ \\
\hline $\begin{array}{l}\text { 2. Improve customer retention statistics } \\
\text { and position in the marketplace through } \\
\text { business intelligence capabilities }\end{array}$ & & $\mathrm{G}^{*}$ & $\begin{array}{l}\mathrm{M}^{*} \\
\mathrm{G}^{* *}\end{array}$ & $\begin{array}{l}\mathrm{M}^{*} \\
\mathrm{G}^{* *}\end{array}$ & $\mathrm{G}^{*}$ & & $\mathrm{G}^{*}$ & $\mathrm{G}^{*}$ & & & $\mathrm{G}^{* *} \mathrm{~S}^{*}$ \\
\hline $\begin{array}{l}\text { 3. Improve the reliability, consistency } \\
\text { and responsiveness of service provision, } \\
\text { using integrated IT systems to enable } \\
\text { delivery across multiple channels }\end{array}$ & & & $\mathrm{M}^{*}$ & $\mathrm{G}^{*}$ & & & & $\begin{array}{l}\mathrm{M}^{* *} \\
\mathrm{G}^{* * *}\end{array}$ & & & $\mathrm{G}^{*} \mathrm{~S}^{*}$ \\
\hline $\begin{array}{l}\text { 4. Improve overall company } \\
\text { performance by making business } \\
\text { processes more effective }\end{array}$ & & & & $\mathrm{G}^{* *}$ & & & & $\mathrm{G}^{* *}$ & & $\mathrm{G}^{*}$ & $\mathrm{G}^{*}$ \\
\hline $\begin{array}{l}\text { 5. Enhance the customers' total } \\
\text { experience through improved strategic } \\
\text { and marketing decision-making, and } \\
\text { ability to target specific customer } \\
\text { segments }\end{array}$ & $\begin{array}{l}\mathrm{M}^{*} \\
\mathrm{G}^{* * *}\end{array}$ & & $\begin{array}{l}\mathrm{M}^{*} \\
\mathrm{G}^{* *}\end{array}$ & $\mathrm{G}^{*}$ & & & & $\mathrm{G}^{*}$ & & $\mathrm{G}^{*}$ & $\mathrm{G}^{* *}$ \\
\hline
\end{tabular}

Similar analysis was carried out between the applications and the five objective factors. Results are shown in Table 5. This reveals that (if the $G^{*}$ results are again ignored) interactive selling, field service, content management, incentive compensation and partner relationship applications are not significantly associated with any of the objective factors. The four applications that are currently installed by a majority of respondents all appear to satisfy at least one objective factor, or part of it. Analytical applications help to enhance the customers' total experience. Opportunity and lead management applications support better management of new opportunities and sales leads. Campaign management software appears to add the most value to CRM objectives. It helps to improve customer retention statistics and position in the marketplace, improves service provision across multiple channels, and enhances the customers' total experience. Call centre applications improve customer retention statistics and position in the marketplace, and assist overall company performance.

The links of personalisation applications with objective factors are also somewhat surprising. They are strongly associated with reliable, consistent and responsive service provision, and delivery across multiple channels, as well as improving overall company performance. Sales configuration applications are owned by only $21 \%$ of respondents, and $74 \%$ are not considering their purchase. Yet they are significantly associated with management of new opportunities and sales leads. It is quite possible that this application is generally not considered because the area is seen to be adequately taken care of by other software.

Further tests were carried out for any correspondence between objective factor scores and the total number of different types of CRM applications owned by organisations. This number ranged from 1 to 11 , with a median of 6 . Table 5 showed there to be a slight association - the greater the total numbers installed, the more respondents tended to agree with Objective Factors 1, 2, 3 and 5, and to a small extent Factor 4. Overall, allowing for the limitations of the study, there clearly seems to be some misalignment of investment in CRM applications with CRM objectives. This will be discussed later.

\section{Level of CRM customer data integration}

Once the business objectives have been determined and the corresponding enabling IT applications implemented, companies need to determine whether business objectives are being successfully achieved. Pan and Lee (2003) state that to be truly effective, a CRM IT infrastructure must provide internal personnel with a single view of the customer; regardless of how they interact with the company and of which CRM applications they use. Integration of customer data has therefore been used as one measure of the sampled companies' overall CRM IT implementation effectiveness. Respondents were asked the following questions: 
1. Is there a consistent view of customer data across your CRM IT applications, in terms of customer, policy and account details?

2. Do your customers receive a single statement reflecting all account and policy details?

3. Are complaints received in the Customer Service department reflected in the service records of other relevant departments e.g. Marketing and Accounting?

4. Do Marketing and Customer Service departments have access to relevant and accurate policy and account details whilst interacting with the customer?

\section{Integration findings}

The breakdown of responses to these questions is shown in Figure 2. This reveals that respondents are most satisfied with their ability to obtain a consistent view of customer data, and for Marketing and Customer Services to have interactive access to appropriate data.

Only two of the 34 organisations gave an unqualified 'yes' to all four questions, while a further seven said 'yes' to three out of the four. Thirteen organisations answered 'yes' or 'to a degree' to all four questions, implying that 21 , or $62 \%$, answered 'no' to one or more of them. This indicates that a large proportion of respondents, while having many CRM applications in place, are not using their information systems to gain an integrated view of customer data. In particular, $26 \%$ of organisations said that they did not have a consistent view of customer data across their CRM IT applications, while another $24 \%$ answered 'to a degree'. Large and medium organisations were more inclined to have integrated CRM applications than small ones. Spearman correlation and factor analysis on the four questions confirmed that respondents viewed the second (single statement) question differently from the rest. It gained the most 'no' replies, formed a different factor from the other three, and displayed almost no correlation with the other three. These three had a low Cronbach alpha of 0,61, with questions 1 and 4 being significantly correlated $(\mathrm{p}<0,01)$.

\section{Relating level of CRM integration to applications}

Mann-Whitney, Spearman and Gamma tests were carried out to see whether presence or absence of each CRM software application was associated with the answers to each integration question, using the ordinal values of 3 for 'yes', 2 for 'to a degree' and 1 for 'no'. Results are given in Table 6, which includes a column for total number of CRM applications in the organisation and a row for the mean of the three related questions 1,3 and 4 .

From Table 6 no application appears to have a measurable impact on customers receiving a single statement. Personalisation is significantly linked to the other three questions, as is the number of applications owned (to a limited extent). Content management is associated with customer complaints and incentive compensation with customer interaction. Again ignoring the $\mathrm{G}^{*}$ relationships, almost all of the most frequently purchased CRM software applications do not seem to be linked with levels of integration. Possibly that role is fulfilled more by an ERP system, and by a suitable data architecture. The associations that exist, and are mentioned above, do not seem to be intuitive.

\section{Relating level of CRM integration to objective factors}

Similar tests using the Spearman and Gamma statistics were carried out comparing the Objective Factor scores with those of the four Integration questions. Those scoring highly on having a consistent view of customer data were significantly associated with strong levels of agreement for Objective Factors 4 and 5 . Those whose customer complaints were well reflected in other departmental records showed strong agreement with Objective Factors 2 and 3. There were no relationships of any significance for the $2^{\text {nd }}$ and $4^{\text {th }}$ Integration questions, or for Objective Factor 1.

\section{Discussion}

The extent to which organisations have implemented CRM varies greatly, and their definitions of CRM and objectives are similarly diverse. This study is exploratory, with a relatively small sample, and so results need to be treated with caution, and broad extrapolation should not be attempted. It is suggested too that the individual associations, however significant statistically, should not be regarded as a definite indication of linkages between certain objectives and applications. Instead the overall pattern should be noted. There does not generally seem to be strong take-up of apparently relevant CRM applications when organisations agree, and agree strongly, with objectives. A positive relationship is often there, at a fairly lukewarm level, or not there at all. In contrast, many of the statistically significant associations do not seem particularly logical. Use of factor analysis to reduce the many objectives to fewer factors perhaps adds a bit more logic to the associations, but does not produce totally intuitive or stable constructs. Overall the choice of applications does not appear to be adequately aligned with the business objectives.

One of the key aspects of CRM implementation was earlier shown to be organisational alignment, particularly between IT and Marketing (Ryals \& Knox, 2001; Wehmeyer, 2005). Henderson and Venkatraman (1993) did important early work in this area, and Luftman, Papp and Brier (1999) and Luftman and McLean (2004) list key enablers and inhibitors of alignment. Reich and Benbasat (2000:82) identify four factors that influence alignment between IT and business objectives: shared domain knowledge between business and IT executives, IT implementation success, communication between business and IT executives, and connections between business and IT planning processes. 


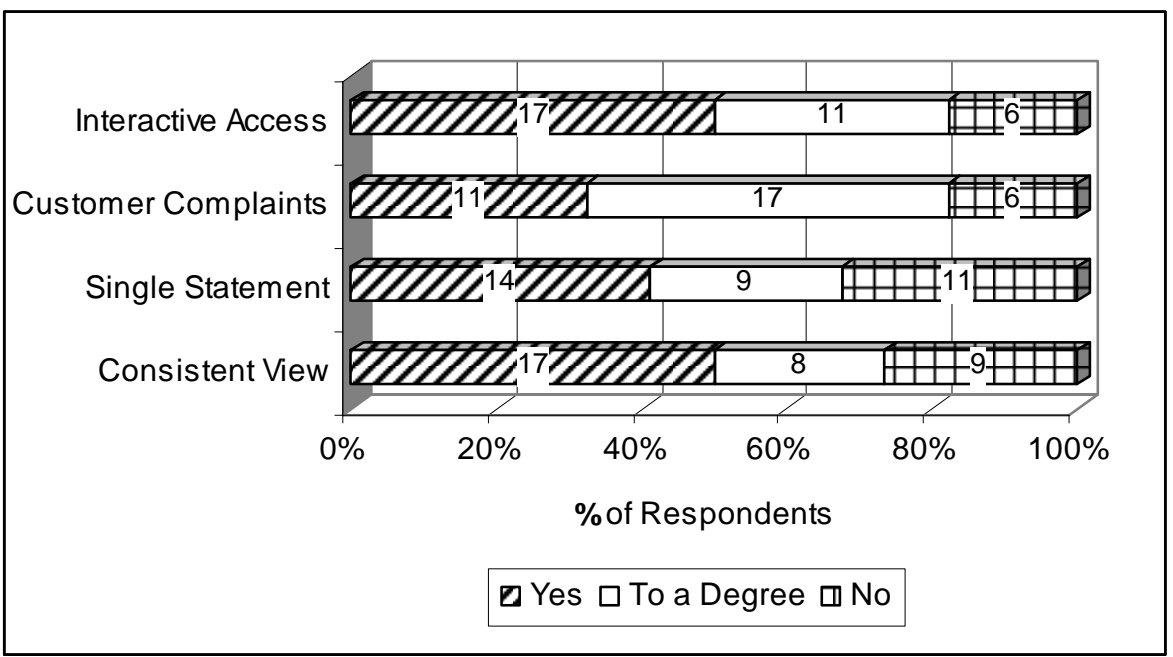

Figure 2: Level of integration of CRM IT applications

Table 6: Associations between integration questions and applications installed

\begin{tabular}{|c|c|c|c|c|c|c|c|c|c|c|c|}
\hline & 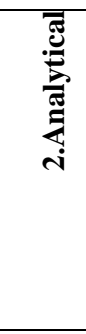 & 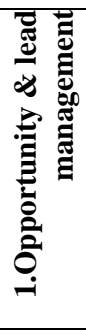 & 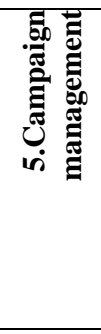 & ن⿺辶寸 & 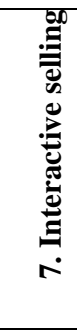 & 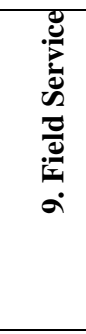 & 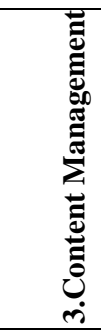 & 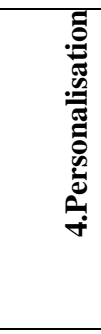 & 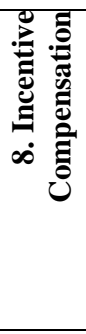 & 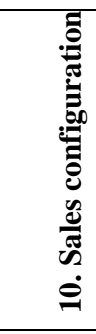 & 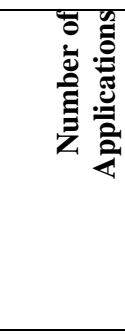 \\
\hline Have Application \% & $76 \%$ & $68 \%$ & $53 \%$ & $56 \%$ & $41 \%$ & $32 \%$ & $44 \%$ & $35 \%$ & $24 \%$ & $21 \%$ & \\
\hline Have or Considering \% & $85 \%$ & $76 \%$ & $65 \%$ & $65 \%$ & $53 \%$ & $50 \%$ & $47 \%$ & $47 \%$ & $38 \%$ & $26 \%$ & \\
\hline \multicolumn{12}{|l|}{ Integration Question } \\
\hline $\begin{array}{l}\text { 1. Is there a consistent view of customer } \\
\text { data across your CRM IT applications, in } \\
\text { terms of customer, policy and account } \\
\text { details? }\end{array}$ & & & $\mathrm{G}^{*}$ & $\mathrm{G}^{*}$ & & & & $\begin{array}{l}\mathrm{M}^{* *} \\
\mathrm{G}^{* * *}\end{array}$ & & & $\mathrm{G}^{*} \mathrm{~S} *$ \\
\hline \multicolumn{12}{|l|}{$\begin{array}{l}\text { 2. Do your customers receive a single } \\
\text { statement reflecting all account and } \\
\text { policy details? }\end{array}$} \\
\hline $\begin{array}{l}\text { 3. Are complaints received in the } \\
\text { Customer service department reflected in } \\
\text { the service records of other relevant } \\
\text { departments e.g. marketing and } \\
\text { accounting? }\end{array}$ & & & & & & & $\begin{array}{l}\mathrm{M}^{*} \\
\mathrm{G}^{* * *}\end{array}$ & $\begin{array}{l}\mathrm{M}^{*} \\
\mathrm{G}^{* *}\end{array}$ & $\mathrm{G}^{*}$ & & $\mathrm{~S}^{*}$ \\
\hline $\begin{array}{l}\text { 4. Do marketing and customer service } \\
\text { departments have access to relevant and } \\
\text { accurate policy and account details } \\
\text { whilst interacting with the customer? }\end{array}$ & & & $\mathrm{G}^{*}$ & & & & & $\begin{array}{l}\mathrm{M}^{*} \\
\mathrm{G}^{* *}\end{array}$ & $\begin{array}{l}\mathrm{M}^{*} \\
\mathrm{G}^{* *}\end{array}$ & & $\mathrm{~S}^{*}$ \\
\hline Mean of Question 1, 3 and 4 & & & $\mathrm{G}^{*}$ & & & & $\begin{array}{l}\mathrm{M}^{*} \\
\mathrm{G}^{*} \mathrm{~S}^{*}\end{array}$ & $\begin{array}{l}\mathrm{M}^{* * *} \\
\mathrm{G}^{* * *} \\
\mathrm{~S} * * *\end{array}$ & $\mathrm{G}^{*}$ & $\mathrm{G}^{*}$ & $\mathrm{G}^{* *} \mathrm{~S}^{* *}$ \\
\hline
\end{tabular}


The sample of South African organisations did not have well integrated systems from the customer viewpoint. Improvements in integration should enhance customer service as well as internal company performance. The ability to improve company performance by making business processes more effective (Objective Factor 4) may be more reliant on the efficient integration of systems and data than the implementation of individual applications.

It was initially hoped that results of this research could be compared with those from the Henley study. However, McCalla (2003) points out a range of problems that occurred with obtaining responses for the British survey, and it appears as if it was not completed.

\section{Conclusions and recommendations}

The 34 South African organisations sampled rated the importance of a broad set of business objectives for CRM, many customer-focussed, and others concerned with internal efficiency. Only four of the eleven CRM software application components were installed by a majority of the respondents, and the majority were not even considering the installation of another five of them. High levels of agreement with objectives did not correspond very often with increased incidences of application installation, particularly with the higher ranked objectives. On the whole, organisations analysed did not seem to have well integrated customer information. There seemed to be a basic lack of alignment in two ways: between business objectives and CRM software purchased; and also in terms of crossfunctional integration and processes.

Management faces a significant challenge. In studies of key information systems management issues since 1983 in the United States and since 1989 in South Africa, IT and Business Alignment has always ranked in the top ten for systems generally. The very fact that CRM includes the words 'customer' and 'relationship' implies that areas are being dealt with that are much less predictable and controllable than manufacturing or financial information. Consciousness has certainly been raised in recent years about the importance of joint planning and implementation of information systems, but this must continue to be strongly emphasised, and cross-pollination of knowledge about the areas of Marketing and IT is vital. At the same time, the literature review and the results of this survey show that there is great potential for academics to undertake further research into many aspects of CRM.

\section{Acknowledgement}

The author would like to thank staff of Henley Management College for providing a copy of their questionnaire, and Jonathan Adams, Bradley Coomer, Jacob Huisamen and Wilko Nienhaus for their assistance in data collection and initial analysis.

\section{References}

Abratt, R. \& Russell, J. 1999. 'Relationship marketing in private banking in South Africa', International Journal of Bank Marketing, 17(1):5-19.

Berry, L. 1983. Relationship marketing. In Berry, L., Shostack, G.L. \& Upah, G.D. (Eds.). Perspectives in services marketing. Chicago: American Marketing Association.

Brink, A. \& Berndt, A. 2004. Customer relationship management \& customer service. Lansdowne, Cape Town: Juta \& Co.

Bull, C. 2003. 'Strategic issues in customer relationship management (CRM) implementation', Business Process Management Journal, 9(5):592-602.

Chen, I. J. \& Popovich, K. 2003. 'Understanding customer relationship management (CRM): People, processes and technology', Business Process Management Journal, 9(5):672-688.

Chen, J. \& Ching, R. 2004. 'An examination of the effects of information and communication technology on customer relationship management and customer lock-in'. In Proceedings of the Tenth Americas Conference on Information Systems. New York, USA: Association for Information Systems, pp. 3902-3913.

Chen, Q. \& Chen, H-M. 'Exploring the success factors of eCRM strategies in practice', Database Marketing \& Customer Strategy Management, 11(4):333-343.

Christopher, M., Payne, A. \& Ballantyne, D. 1991. Relationship marketing: bringing quality, customer service and marketing together. Oxford: Butterworth-Heinemann.

Collins, K., Herschel, G. \& Sarner, A. 2005. Hype cycle for CRM marketing applications 2005. 16 June 2005, Gartner Group.

Cosgrove Ware, L. 2003. 'CRM: Desperately seeking success’, CIO Magazine, 1 August.

Croteau, A-M. \& Li, P. 2003. 'Critical success factors of CRM Technological Initiatives', Canadian Journal of Administrative Sciences, 20(1):21-34.

Everitt, B.S. \& Dunn, G. 1991. Applied multivariate data analysis. London: Edward Arnold.

Ezingeard, J.-N., Nolan, R. \& Money, A. 2001. 'A taxonomy of objectives of IT-enabled customer relationship management as a basis of evaluation of CRM success'. In Eighth European Conference on Information Technology Evaluation, Oriel College, Oxford. Reading, U.K.: MCIL, pp. 519-526

Gartner Group. 2003. 'CRM success is in strategy and implementation, not software'. [online] URL:http://www.gartner.com. Accessed 3 March, 2003). 
Goodhue, D.L., Wixom, B. \& Watson, H.J. 2002. 'Realizing business benefits through CRM: Hitting the right target in the right way’, MIS Quarterly Executive, 1(2):79-94.

Greenberg, P. 2001. CRM at the speed of light. Berkeley: McGraw-Hill.

Hart, M.L., Berkowitz, S., Ryan, J. \& Waspe. K. 2004. ‘Key information systems management issues: A comparative study in South Africa', South African Journal of Business Management, 35(4):49-59.

Hart, S., Hogg, G. \& Banerjee, M. 2004. 'Does the level of experience have an effect on CRM programs? Exploratory research findings', Industrial Marketing Management, 33(6):549-560.

Henderson, J. C. \& Venkatraman, N. 1993. 'Strategic alignment: Leveraging information technology for transforming organizations', IBM Systems Journal, 32(1):416.

Jayachandran, S., Sharma, S., Kaufman, P. \& Raman, P. 2005. 'The role of relational information processes and technology use in customer relationship management', Journal of Marketing, 69(October):177-92.

Kale, S. H. 2004. 'CRM failure and the seven deadly sins', Marketing Management, Sept/Oct:42-46.

Karimi, J., Somers, T.M. \& Gupta, Y.P. 2001. 'Impact of information technology management practices on customer service', Journal of Management Information Systems, 17(4):125-158.

Kumar, V. \& Reinartz, W.J. 2006. 'Customer relationship management: A databased approach'. Hoboken, New Jork: John Wiley \& Sons.

Luftman, J.N. 2005. 'Key issues for IT executives 2004', MIS Quarterly Executive, 4(2): 269-285.

Luftman, J.N. \& McLean, E.R. 2004. 'Key issues for IT executives’, MIS Quarterly Executive, 3(2):89-104.

Luftman, J.N., Papp, R. \& Brier, T. 1999. 'Enablers and inhibitors of business-IT alignment', Communications of AIS, 1(11):1-33.

McCalla, R. 2003. 'Getting results from online surveys Reflections on a personal journey', Electronic Journal of Business Research Methods, 2(1):55-62.

McCalla, R., Ezingeard, J.-N. \& Money, A. 2002. 'ITenabled customer relationship management: An exploratory construct development from the content analysis of vendors claims' In Ninth European Conference on Information Technology Evaluation, Universite Paris-Dauphine. Reading, U.K.: MCIL, pp. 307-316

McKim, B. 2002. 'The differences between CRM and database marketing', Journal of Database Marketing, 9(4):371-375.
Mithas, S., Krishnan, M.S. \& Fornell, C. 2005. 'Why do customer relationship management applications affect customer satisfaction?', Journal of Marketing, 69:201-209.

Murthi, B.P.S. \& Sarkar, S. 'The role of the management sciences in research on personalisation', Management Science, 49(10):1344-1362.

Nairn, A. 2002. 'CRM: Helpful or full of hype?', Journal of Database Marketing, 9(4):376-382.

Ngai, E.W.T. 2005. 'Customer relationship management research 1992-2002: An academic literature review and classification', Marketing Intelligence and Planning, 23(6):582-605.

Pan, S.L. \& Lee, J.-N. 2003. 'Using e-CRM for a unified view of the customer', Communications of the ACM, 46:9599.

Park, C. \& Kim, Y. 2003. 'A framework of dynamic CRM: Linking marketing with information strategy', Business Process Management Journal, 9(5):652-671.

Paulissen, K., Milis, K. \& Brengman, M. 2005. 'Customer relationship management systems research: Voids in the current literature'. In Proceedings of the Eleventh Americas Conference on Information Systems, 11-14 August, Omaha, Nebraska. Omaha: Association for Information Systems, p.p.194-204.

Payne, A. \& Frow, P. 2004. 'The role of multichannel integration in customer relationship management', Industrial Marketing Management, 33:527-538.

Peppers, D. \& Rogers, M. 1993. The one to one future. New York: Doubleday.

Peterson, R. 2003. 'Electronic customer relationship management: Evaluating strategic capabilities across stages of innovation'. In Proceedings of the $10^{\text {th }}$ European Conference on Information Technology Evaluation, Madrid. Reading, U.K.: MCIL, pp. 513-524

Reich, B.H. \& Benbasat, I. 2000. 'Factors that influence the social dimension of alignment between business and information technology objectives', MIS Quarterly, 24(1):81-113.

Reichheld, F. 1996. The loyalty effect: The hidden force behind growth, profits and lasting value. Boston: Harvard Business School Press.

Reinartz, W., Krafft, M. \& Hoyer, W. 2004. 'The customer relationship management process: Its measurement and impact on performance', Journal of Marketing Research, 41(August):293-305.

Reinartz, W. \& Chugh, P. 2002. 'Learning from experience: Making CRM a success at last', Call Center Management, 4(3):207-19. 
Rigby, D., Reichheld, E. \& Schefter, P. 2002. 'Avoiding the four perils of CRM', Harvard Business Review, 80(2):101109.

Roberts, M., Liu, R. \& Hazard, K. 2005. 'Strategy, technology and organisational alignment: Key components of CRM success', Database Marketing \& Customer Strategy Management, 12(4):315-326.

Romano, N.C. Jr. \& Fjermestad, J. 2002. 'Electronic commerce customer relationship management: An assessment of research', International Journal of Electronic Commerce, 6(2):61-113.

Ryals, L. \& Knox S. 2001. 'Cross-functional issues in the implementation of relationship marketing through customer relationship management', European Management Journal, 19(5):534-542.

Siegel, S. \& Castellan, N.J. 1988. Nonparametric statistics for the behavioural sciences. Singapore: McGraw-Hill.

Sigala, M. 2004. 'Customer relationship management (CRM) evaluation: Diffusing CRM benefits into business processes'. In $12^{\text {th }}$ European Conference of Information Systems, Turku, Finland. Association of Information Systems e-Library, pp. 1-12

Sigala, M. 2005. 'Integrating customer relationship management in hotel operations: Managerial and operational implications', International Journal of Hospitality Management, 24: 391-413.

Sin, L.Y.M., Tse, A.C.B. \& Yim, F.H.K. 2005. 'CRM: Conceptualization and scale development', European Journal of Marketing, 39(11/12):1264-1290.

Swift, R.S. 2002. 'Executive response: CRM is changing our eras, the information we require and our processes', MIS Quarterly Executive, 1(2):95-96.

Thompson, E. 2005. 'Beyond CRM: The scenario for customer-centric strategies'. In Gartner Symposium/ITXPO 2005, 1-3 August, Cape Town. Gartner Group.

Van Zyl, C.R. 2005. 'Customer relationship management captures intellectual capital for increased competitiveness', Acta Commercii, 5:70-83.

Verhoef, P.C. 2003. 'Understanding the effect of customer relationship management efforts on customer retention and customer share development', Journal of Marketing, 67(October):30-45.

Wehmeyer, K. 2005. 'Aligning IT and marketing - the impact of database marketing and CRM', Database Marketing \& Customer Strategy Management, 12(3): 243256.

Winer, R. 2001. 'A framework for customer relationship management', California Management Review, 43(4):89106.
Xu, M. \& Walton, J. 2005. 'Gaining customer knowledge through analytical CRM', Industrial Management and Data Systems, 105(7):955-971.

$\mathrm{Yu}$, L. 2001. 'Successful customer relationship management', MIT Sloan Management Review, 42(Summer):18-19.

Zablah, A.R., Bellenger, D.N. \& Johnston, W.J. 2004a. 'An evaluation of divergent perspectives on customer relationship management: Towards a common understanding of an emerging phenomenon', Industrial Marketing Management, 33(6):475-489.

Zablah, A.R., Bellenger, D.N. \& Johnston, W.J. 2004b. 'Customer relationship management implementation gaps', Journal of Personal Selling \& Sales Management, 24(4):279-295. 
Appendix 1 - Response Breakdown to All 26 CRM Objectives

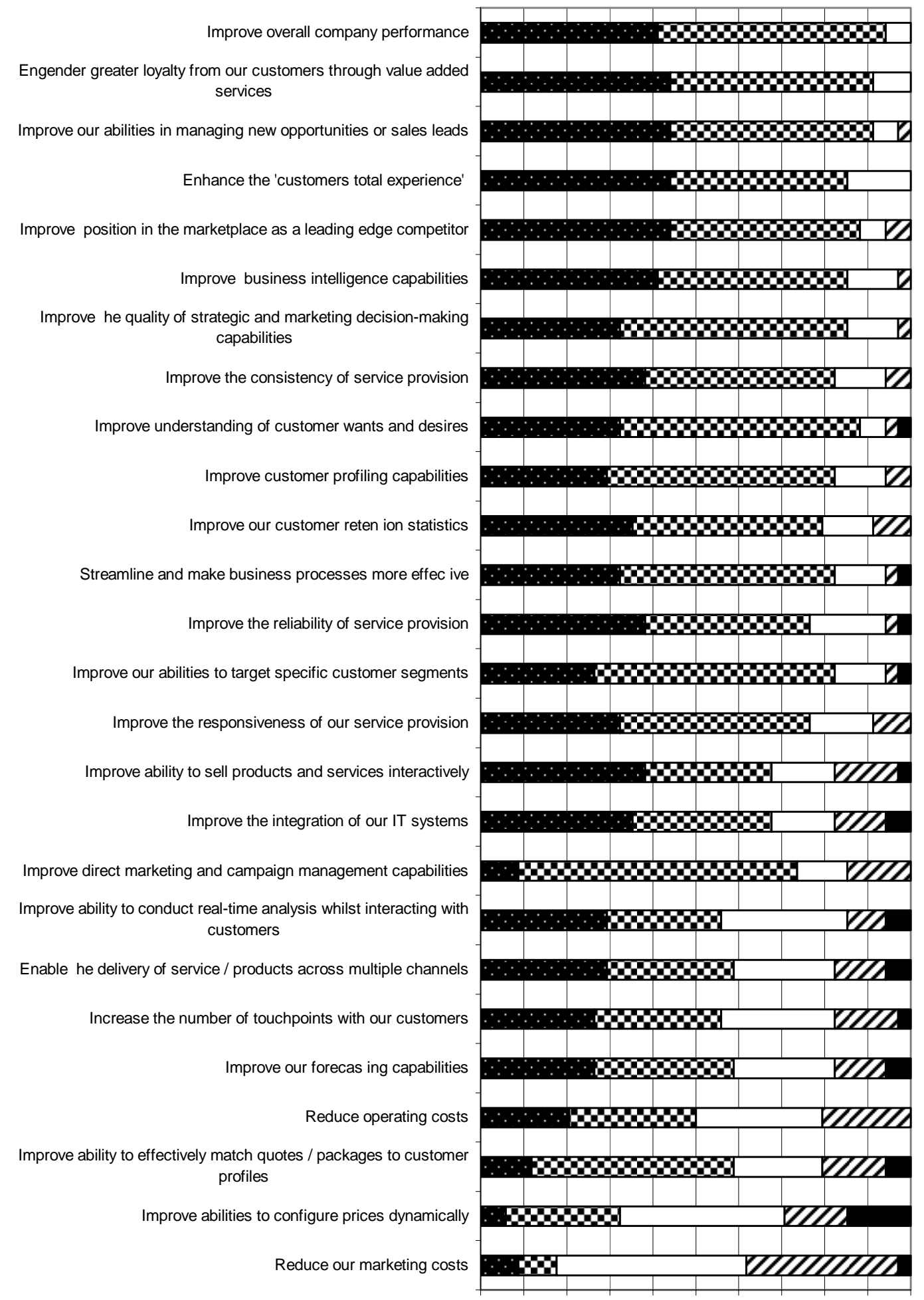

0\% 10\% 20\% 30\% 40\% 50\% 60\% 70\% 80\% 90\% 100

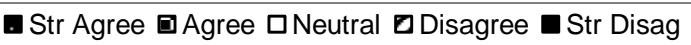

